Association for Information Systems

AIS Electronic Library (AISeL)

ICEB 2003 Proceedings

International Conference on Electronic Business

(ICEB)

Winter 12-9-2003

Prioritizing Service Quality Dimensions

Nimit Chowdhary

Bhagwati P. Saraswat

Follow this and additional works at: https://aisel.aisnet.org/iceb2003

This material is brought to you by the International Conference on Electronic Business (ICEB) at AIS Electronic Library (AISeL). It has been accepted for inclusion in ICEB 2003 Proceedings by an authorized administrator of AIS Electronic Library (AISeL). For more information, please contact elibrary@aisnet.org. 


\section{Prioritizing Service Quality Dimensions}

\author{
Dr. Nimit Chowdhary \\ Department of Management Studies \\ Maharshi Dayanand Saraswati University \\ Ajmer 305009 Rajasthan \\ India \\ nimitchowdhary@hotmail.com
}

\author{
Dr. Bhagwati P. Saraswat \\ Department of Commerce \\ Maharshi Dayanand Saraswati University \\ Ajmer 305009 Rajasthan \\ India \\ drpraveenm@hotmail.com
}

\begin{abstract}
Researchers all over have discussed and debated the contents of service quality. Multidimensionality of the service quality construct has been proposed. Further, researchers have attempted to prioritize the service quality dimensions. Authors have, as a part of a larger research initiative have made an attempt to analyze the prioritization among different service dimensions across different services types based on nature of service act and target of service act. Authors have concluded that a generalization of priority across all service types is not admissible. They also suggest different weights for different service quality dimensions depending upon the service types.
\end{abstract}

\section{Introduction}

In the 'age of customer', delivering quality service is considered an essential for success and survival [12], [18], [22] and [28]. What constitutes service quality has attracted the attention of researchers all over the world. The debate continues.

Johnston [14] suggests that one of the pressing issues before services research concerns the identification of the determinants of service quality. This should be a central concern for service management academics and practitioners, as the identification of the determinants of service quality is necessary in order to be able to specify, measure, control, and improve customer perceived service quality.

Early studies during 1980s focused on determining what service quality meant to customers and developing strategies to meet customer expectations [18]. The early pioneers of services marketing in Europe, especially the Nordic School, argued that service quality consists of two or three underlying dimensions. Lehtinen and Lehtinen [16] referred to physical and interactive quality while Christian Gronroos [13] identified a technical dimension, a functional dimension and the firm's image as a third dimension. In later years, Parasuraman, Zeithaml and Berry [18] published empirical evidence from five service industries that suggested that five dimensions more appropriately capture the perceived service quality construct. Building on the pioneering work of the Nordic School of services management and particularly Christian Gronroos, they established service quality as the core of services marketing. Their landmark article in 1985 conceptualized service quality as a gap between consumers' expectations and perceptions [18] inspired many other researchers to examine the services quality construct within a marketing premise [2]. However, their contribution has not gone unchallenged. Much of this interest has centered on the controversy generated by their Service Quality Gaps Model [18], and particularly the SERVQUAL instrument developed to measure service quality [19]. Many researchers who have used the SERVQUAL instrument have been critical of its paradigmatic foundation, its convergent and discriminant validity, the use of difference scores and the use of negatively phrased items [5], [1], [21] and [4].

Variations from unidimensionality [11] to two, three, four, six and eight factor structures have been reported [1], [3], [5], [10], and [25]. Spreng and Singh [26] have hinted at the possible combination of some of the five dimensions due to high inter-correlations. Johnston and Silvestro [15] went on to add the customer's perspective to the 12 service quality characteristics. This led to the identification of an additional five service quality determinants: attentiveness/ helpfulness, care, commitment, functionality, integrity; it also led to a refining of some of the other definitions.

A number of other authors have also postulated their own determinants of service quality, though in some cases they appear to 
have been based on Berry et al.'s [2] wellpublicized work.

Lately even the developers of the instrument have produced evidence confirming the doubts expressed about the five-dimensional configuration. Thus, despite the 'many' studies which have analysed the dimensions measured by SERVQUAL, 'there is no clear consensus on the number of dimensions and their interrelationships'. This uncertainty hampers our understanding of service quality and casts doubts over the use of the SERVQUAL instrument in future research. It also shows that a considerable amount of research still needs to be done concerning the dimensionality of perceived service quality in general and SERVQUAL in particular, as called for by its developers [20].

Chowdhary and Prakash [9] have suggested a two factors' theory -that a more detailed approach is required wherein each factor needs to be considered independently and not as an aggregate dimension. They report evidence to support two-factor theory for services that was discarded by earlier researchers. They argue to differentiate between the factors and the outcome of performance along these factors. The study describes the two factors as 'vantage factors' and 'qualifying factors'. Marketers need to be selective in that certain factors behave as vantage factors while others as qualifying factors. The two are different in nature and require a differential treatment.

\section{Relative importance of dimensions}

Parasuraman et al. [19] have observed that their instrument (SERVQUAL) can be used to evaluate the relative importance of the dimensions of quality in influencing customers' overall perceptions of a service. The relative weight that customers seem to give to each quality dimension can be determined. One of the important result that has been reported in the early studies of relative importance is that customers are quite consistent in both their imputed and their direct rankings of the importance of the service quality attributes. In this key study, reliability was demonstrated to be the most important dimension and empathy (a composite of understanding and access) the least important across a seemingly wide array of service types. Zeithaml et al. [28] also report, using a variation of SERVQUAL that tangibles proves to be consistently unimportant. A pertinent question here is that whether such a generalization is possible. Chowdhary [8] suggest that generalizations are difficult to make because of variation in the basic nature of services (labor or capital intensity) and that the type of industry affect the design of service. It was seen that empathy and responsiveness were found to be more important for labor intensive industry while tangibles and reliability affected the assessment of quality dimensions in case of capital intensive services. This was also confirmed by the results from a similar study done for 'Management Education' where the single most important dimension was the knowledge of the teacher (assurance).

Services USP (unique selling proposition) can be woven around different criteria (tangibility, customization, labor intensity, etc.). This criterion in turn could be the KPD (key performance dimension). Different user groups can see each type of service in turn as performing on a number of factors across different dimensions. From among these factors, some are the key factors and are relatively more important for the consumer. A number of these KFs could be simultaneously important for these user groups, though the relative importance of these dimensions may vary from one user group to another. There may also be a general shift in consumer preference for a dimension for example from 'medical-care' through 'patientcare' to 'hospital-care', incase of the consumers of healthcare. Their importance may also vary from one consumer to another.

\section{Service types}

Service classifications have been offered since early 1980s. Different authors have suggested different taxonomies based on different criterions. Of these four are note worthy- Chase [6], Chase and Tansik [7], Schmenner [24], Wemmerlov [27] and Lovelock [17]. Chase segments by the extent of customer contact in the delivery of the service. Schmenner classifies services using two dimensions, with the degrees of interaction (generalized from "contact") and customization on one axis and the degree of labour intensity on the other. Wemmerlov [27] more recently proposed a classification scheme where the variables of differentiation are the degree of routinization of the process, the "object" of the service process, and customer contact. His operationalization of contact differs from both Chase and Schmenner in that he redefines it to be "direct", "indirect" or "no" contact with the customer, rather than simply as "high" or "low". Lovelock [17] has suggested categorizing services into four distinctive categories based on what a service 
organisation is actually processing and how does it perform that task. A service organisation may be servicing individual customers or alternatively it may be servicing their possessions. Further the servicing may be physical as in case of hair cutting or a travel by train. Alternatively, the servicing may be intangible as in case of education, entertainment or consultancy. He therefore suggests a 2X2 classification of service processes.

\begin{tabular}{|c|c|c|c|}
\hline \multicolumn{4}{|c|}{ Table 1: Population for Study } \\
\hline & & \multicolumn{2}{|c|}{$\begin{array}{l}\text { Who or what is the recipient of the } \\
\text { service? }\end{array}$} \\
\hline & & People & Possessions \\
\hline \multirow{2}{*}{ 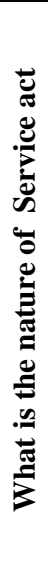 } & 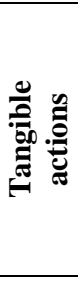 & $\begin{array}{l}\text { People } \\
\text { Processing } \\
\text { - Hospitals and } \\
\text { nursing homes } \\
\text { - Hotels } \\
\text { - Beauty saloons } \\
\text { - Fitness Centers }\end{array}$ & $\begin{array}{l}\text { Possession } \\
\text { Processing } \\
\text { - Freight } \\
\text { transportation } \\
\text { - Repair shops } \\
\text { - Retail outlets } \\
\text { - Laundry and dry } \\
\text { cleaning } \\
\end{array}$ \\
\hline & 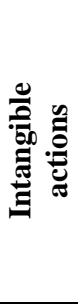 & $\begin{array}{l}\text { Mental Stimuli } \\
\text { Processing } \\
\text { - Telephone } \\
\text { companies } \\
\text { - Management } \\
\text { consulting } \\
\text { - MBA } \\
\text { Education } \\
\text { - Cable operators }\end{array}$ & $\begin{array}{l}\text { Information } \\
\text { Processing } \\
\text { - Accounting firms } \\
\text { - Banks } \\
\text { - Insurance } \\
\text { - Legal services }\end{array}$ \\
\hline
\end{tabular}

\section{Research issue}

The above cited literature review has discussed the service dimension and the tools to evaluate service quality. Yet it is insufficient is establishing any generic relative importance of service dimensions. Researcher believes that such a generalization may not be possible across all service types. This study seeks to make out whether some generalization is possible within service types and does that vary with classification variables. For the purpose of investigation, researcher has used Lovelock's classification.

The pertinent research question was whether the different categories of service processes show a pattern vis-à-vis the importance of different determinants of service quality (the five dimensions suggested by Parasuraman, et al.). The objective was to identify the relative importance of service quality dimensions for different service processes.For each category, four different services were identified. Thus in all sixteen services were identified. Respondents were asked to free list what they felt was important and added value to their consumption of a particular service type. A survey of 356 respondents returned a 989 free-list items shown in table 2.

In the next phase of analysis, the free list items were classified using the five dimensions of Parasuraman et al. It was observed the price with reference to cost, fees, charges, discounts, etc. figured repeatedly and so it was categorized separately as the sixth dimension and was called 'fees'. For a list for any particular service type, we could now generate the relative importance matrix using tally marks. These were then converted into percentile scores. Thus, we could get a score for each dimension for each service type. Similarly, the score were calculated for each service process category.

\section{Discussion}

First, the six service quality dimensions corresponding to each of the service types were ranked based on the mean scores for the subset of four services comprising each group.

If any the ranks of service dimensions across each service type were similar, some kind of generalization of relative importance of dimensions was possible. It was decided to test the following hypothesis.

$\mathbf{H}_{\mathbf{0}}: \rho_{\mathrm{s}}=\mathbf{0}$

Null Hypothesis: There is no rank correlation in the population; that is, different types of services have dimensions (tangibility, reliability, responsiveness, assurance, empathy, and fees) having different priorities (ranks).

$\mathbf{H}_{0}: \rho_{s} \gamma \mathbf{0}$

Alternative Hypothesis: There is population rank correlation; that is, irrespective of the service types, dimensions have similar priorities (ranks). 


\begin{tabular}{|c|c|c|c|c|}
\hline \multicolumn{5}{|c|}{$\begin{array}{l}\text { Table 2a: Spearman's } \\
\text { rank correlation }\left(r_{s}\right) \text { test }\end{array}$} \\
\hline & 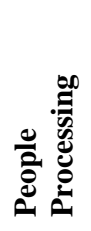 & 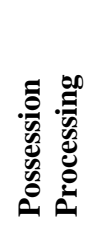 & 总 & 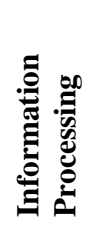 \\
\hline $\begin{array}{l}\text { People } \\
\text { Processing }\end{array}$ & 1.00 & -0.03 & -0.47 & -0.31 \\
\hline \begin{tabular}{|l|} 
Possession \\
Processing
\end{tabular} & & 1.00 & 0.56 & 0.26 \\
\hline $\begin{array}{l}\text { Mental Stimuli } \\
\text { Processing }\end{array}$ & & & 1.00 & 0.53 \\
\hline $\begin{array}{l}\text { Information } \\
\text { Processing }\end{array}$ & & & & 1.00 \\
\hline
\end{tabular}

For small values of $n \quad(n=6)$, we use Spearman's rank correlation test tables that give values for combined areas in both tails.

\section{Table 2b: Spearman's rank}

\section{correlation test tables}

\begin{tabular}{|l|l|l|l|l|l|}
\hline $\mathbf{N}$ & $\mathbf{0 . 0 2}$ & $\mathbf{0 . 1 0}$ & $\mathbf{0 . 0 5}$ & $\mathbf{0 . 0 2}$ & $\mathbf{0 . 0 1}$ \\
\hline 6 & 0.600 & 0.771 & 0.829 & 0.886 & 0.943 \\
\hline
\end{tabular}

Thus, null hypothesis was accepted at all the abovementioned levels of significance. It can therefore be concluded that for different service types, consumers rate service quality dimensions differently. This supports Rosen and Karwan's study [23] that the proposition that one can generically order the quality dimensions (in terms of relative importance as suggested by Parasuraman, et al [20]) for any firm is appealing, but is not likely to be supportable. The reasons for this are intuitive from a strategic operations perspective and are observable when conducting the tests for 'relative importance' across a truly broad sample of service types.

Subsequently, two-step cluster analysis procedure was deployed to reveal natural grouping (or clusters) within a data set for each service quality dimension that would otherwise not be apparent. Similarity between clusters was computed on the basis of log-likelihood method. The likelihood measure places a probability distribution on the variables. Continuous variables (tangibility, reliability, responsiveness, assurance, empathy and fees) were assumed to be normally distributed, while categorical variable (service type) are assumed multinomial.
Further, all variables are assumed to be independent. Empirical internal testing indicates that the procedure is fairly robust to violations of both the assumption of independence and the distributional assumptions. One important observation is that two-way cluster analysis in almost all cases (5 out of 6 , barring reliability) resulted in 2 X 2 distributions of service types.

Once the clusters were obtained, based on Euclidean measure of distance test of differences between cluster means for small sample sizes was applied to ensure if the difference in clustermeans in significant or not at $\cos =0.05$.

Tangibility is clearly an important issue with services that require a more visible action that is people-processing (A) and possession-processing (B) services. Perhaps tangible cues buttress tangible actions for these cases. Customers need more tangibility to identify with services where value is created in their physical presence on the service process. Since the presence of customer is not a concern in case of services with an intangible action, customers of mental-stimuli (C) and information processing (D) have rated tangibles as low on expectations. Still it must be noted that need for tangibility is higher as we move from services targeted at possessions to services those are targeted at people (39.64 (A)> 19.758 (B); 8.34 (C)> 6.19 (D)). Tangibility, therefore, is more important an issue for universities and cinema halls than for insurance companies and accounting firms. Thus tangibility is most important for people processing services followed by possession processing, mental-stimuli processing and information processing services in that order.

Respondents from the services selected for the study rated reliability as the most important service dimension. As in most cases of services, only a post purchase evaluation is possible, customers expect service processes to be reliable to match their expectations. In case of this dimension two-step cluster analysis resulted into two clusters with people processing services as one cluster and the other three being included in the second cluster. Respondents for cluster one, are relatively less concerned about reliability perhaps because tangibility serves as a surrogate for it. All the others in cluster two rate it as quite important $($ Mean $=34.22$, s.d. $=7.12)$. Further, as we move towards services that are targeted at possessions of customers, whereby the presence of customer on the process is not necessary and the services are carried out largely in backoffices, there is a greater need for reliability of service process. More reliability is expected as 
services include intangible actions. Thus, reliability is very important for information processing services (ATM-deposit, or ability of your lawyer) followed by possession processing, mental-stimuli processing and least important in case of people processing services.

Cluster analysis clubbed people-processing and information-processing as one cluster; and possession-processing and mental-stimuliprocessing as the second cluster, for "assurance" dimension. Test of difference between means of two clusters was administered to ascertain if there was a significant difference in the means of two clusters. Analysis suggested null hypothesis to be accepted, that is there was no significant difference in the means. Subsequently, two clusters $((\mathrm{A}, \mathrm{C})$ and $(\mathrm{B}, \mathrm{D}))$ based on distance of mean values of four service-types were formed and the test for differences was applied. A tvalue of 2.38 ( $>2.145$ the critical value) was obtained and the alternate hypothesis was accepted. The difference in means was significant at $\cos =0.05$ for one tailed test.

Assurance, the knowledge and courtesy of employees and their ability to convey trust and confidence (competence, courtesy, credibility, security) was important for services targeted at the individual customers necessitating considerable contact between the employees and customers $((\mathrm{A}=22.33)$ and $(\mathrm{C}=28.42))$. Further, as the nature of service act grows more intangible the need for greater assurance was felt (C (28.42) > A (22.33) and D (19.36) > B (17.43)) to reinforce the confidence of customer. Thus customers of mental-stimuli-processing services (C) that require meaningful customer contact and are largely intangible (MBA teaching, management consulting, etc.), expect greater assurance from service providers. Subsequently, the importance of assurance decreases in the order: people-processing, information processing and last the possession processing.

Test of difference of means based on both, the two-step cluster analysis and distance, for responsiveness, suggested accepting null hypothesis. That is no grouping of service types was available that results into significant difference to suggest that responsiveness was more important in any one of service types or groups. In fact, responsiveness was uniformly considered as less important service dimension by respondents of all service types. In these times of transition, ours is still a deficit market economy. The customers are less expectants and waiting time is often not a big consideration. The customer therefore accepts less spontaneity and slothfulness in service delivery. This may change as markets mature over time and customers need to be lured and pampered.

Two-step cluster analysis identified peopleprocessing $(\mathrm{A}=16.71)$ and informationprocessing $(D=23.19)$ services as one cluster (Mean $=19.95$, s.d. $=6.5)$ where empathy is considered important. In people-processing services the presence of customer is substantial that requires service providers to make an extra effort to understand his/ her needs and make the stay pleasant. At the other extreme is a largely intangible service (information processing) to be carried out in back-office away from the customer. The customer's concern is higher-that service be explained to him/ her, and he/she may be understood well before the provider sets out to create the service. A tangible (visible) service is more certain. Further, if it is targeted at a customer's possession the trepidation is less. A video repair service engineer may be less empathic than a lawyer who must appreciate a customer's concern and viewpoint. Similarly, an hotelier must be more conscious of a customer's preferences as he/ she stays with him. Thus, empathy is least with possession-processing services $\quad(B=8.43)$. Mental-stimuli-processing $(C=11.67)$ occupies an intermediate position.

In absence of risk of personal well being (people-processing) or the risk of information processing the other services are generally available in standardized modes in near perfect markets (cable operators, telephone companies, retail outlets, dry cleaning etc.) The choice of provider therefore gets associated with the monetary cost of obtaining the service. Prices for information-processing services are very competitive (bank rates or insurance premium) and therefore the prices of these have a limited affect on purchase decision making $(A=9.06)$. On the other hand, the concern for well-being of self is paramount in case of people-processing services and so the cost of contentment takes a low priority $(\mathrm{D}=5.4)$.

\section{Deduction}

Though certain trends are visible, yet the researcher would like to draw attention to some of the precincts of this study. In most cases, the notions of most of the concepts vary. Different respondents had different connotation of the same word. Say- safety/ security; reliability, credibility and assurance; location, accessibility; etc. were often used interchangeably. Ranking of dimensions also depended on the current state of 
the competition in a particular industry and varied from industry to industry within a service type. While markets have matured for some industries, they are not very competitive for others. Some for example the cable operators, telephony and insurance till recently, have monopolistic tendencies.

Given the sate of competition and market within the different service industries, following can be concluded:

- Tangibility is more important for services with more tangible actions. Further, the importance reduces as one shifts from services targeted at people to service targeted at possessions.

- $\quad$ Need for reliability is more for services with intangible nature of service act. Services targeted at possessions of the customers will also require more reliability.

- Services targeted at the individual of the customer requires more assurance than those targeted at the possessions. Further more assurance will be needed for services with intangible act.

- $\quad$ Responsiveness did not allow for any kind of clustering. Customers ranked it last on priority across different service types. Perhaps they are less expectant for this service dimension.

- Information-processing and peopleprocessing services require more empathy as compared to other two types.

- Prices were considered relatively more important by consumers of possessionprocessing and mental-stimuli processing services.

\section{References}

[1] Babakus, E. and G.W.Boller. "An Empirical Assessment of the SERVQUAL Scale" Journal of Business Research, 1992, Vol.24, pp.253-68.

[2] Berry, L.L., Zeithaml, V.A. and Parasuraman, A.”Quality counts in services, too”, Business Horizons,1985, May-June, pp. 44-52.

[3] Brensinger, R.P and D.M. Lambert. "Can the SERVQUAL Scale Be Generalized to Business-toBusiness Services?”,1990, paper read at the Summer Marketing Educator's Conference, American Marketing Association.

[4] Buttle, F.A. "What Future SERVQUAL?", Proceedings of the 24th European Marketing Academy Conference, 1995, Paris, pp.211-30.

[5] Carman, J.M. "Consumer Perceptions of Service Quality: an Assessment of the SERVQUAL Dimensions”, Journal of Retailing, 1990, Vol.66, No.1, pp.33-55.
[6] Chase, R.B. "Where Does the Customer Fit into the Service Operation", Harvard Business Review, 1978, Vol. 56, November-December, pp. 37-42.

[7] Chase, R.B. and Tansik, D.A. "The Customer Contact Model for Organizational Design”, Management Science, 1983, Vol. 29 No. 9, September, pp. 1,037-50.

[8] Chowdhary, N. "Two factors theory: Quasi experiments with service quality", in Bo Edvardsson, Brown, S.W., et al (2000) QUIS 7- Service quality in the new economy: Interdisciplinary and international dimension, 2000, New York: International Service Quality Association Inc.

[9] Chowdhary, N. and Prakash, M. "Service quality: Revisiting the two factors theory", in proceeding of The First International Conference on Electronic Business, 2001, Hong Kong, December 19-21.

[10] Cliff, A. and C. Ryan. "Do Travel Agencies Measure up to Customer Expectation? An Empirical Investigation of Travel Agencies' Service Quality as Measured by SERVQUAL", Proceedings of the Tourism Down Under Conference, 1994, Massey University, Palmerston North, New Zealand, December, pp.55-78.

[11] Cronin, J.J. and S.A. Taylor. "Measuring Service Quality: a Re-examination and Extension” Journal of Marketing, 1992, Vol.56, pp.55-68.

[12] Dawkins, P. and F. Reichheld, "Customer Retention as a Competitive Weapon," Directors and Boards, 1990, 14 (Summer), 42-47.

[13] Grönroos. C. "A Service Oualitv Model and Its Marketine Implications.” European Journal of Marketing, 1984, Vol. 18, No.4, pp.36-44.

[14] Johnston, R. "The determinants of service quality: Satisfiers and dissatisfiers," International Journal of Service Industry Management, 1995, 6(5): 53-71.

[15] Johnston, R. and Silvestro, R. "The determinants of service quality--a customer-based approach”, in The Proceedings of the Decision Science Institute Conference, San Diego, CA, 1990, November.

[16] Lehtinen, U. and J.R. Lehtinen. "Service Quality: a Study of Quality Dimensions", paper read at the Second World Marketing Congress, University of Stirling, Scotland, 1985.

[17] Lovelock, C. "Classifying Services to Gain Strategic Marketing Insights”, Journal of Marketing, 1983, Vol. 47, summer, pp. 9-20.

[18] Parasuraman, A., V.A. Zeithaml and L.L. Berry. "A Conceptual Model of Service Quality and Its Implications for Future Research", Journal of Marketing, 1985, Vol.49 (Fall), pp.41-50.

[19] Parasuraman, A., V.A. Zeithaml and L.L. Berry. "SERVQUAL: a Multiple-Item Scale for Measuring Consumer Perceptions of Service Quality”, Journal of Retailing, 1988,Vol.64, No.I, pp.12-40.

[20] Parasuraman, A., V.A. Zeithaml and L.L. Berry. "Alternative Scales for Measuring Service Quality: a 
Comparative Assessment Based on Psychometric and Diagnostic Criteria”, Journal of Retailing, 1994, Vol.70, No.3, pp.201-30.

[21] Peter, J., Churchill, G. and Brown, T. "Caution in the Use of Difference Scores in Consumer Research", Journal of Consumer Research, 1993, Vol.19 (March), pp.655-62.

[22] Reichheld, Frederick and Sasser, Jr., W.L. "Zero Defections: Quality Comes to Services," Harvard Business Review, 1990, 68 (September/October), 10511.

[23] Rosen, L.D. and Karwan, K.R. "Prioritizing the dimensions of service quality: An empirical investigation and strategic assessment”, International Journal of Service Industry Management, 1994, Vol. 5, No.4.

[24] Schmenner, R.W. "How Can Service Businesses Survive and Prosper", Sloan Management Review, 1986, Vol. 27 No. 3, pp. 21-32.
[25] Schneider, B., J.K. Wheeler and J.F. Cox. “A Passion for Service: Using Content Analysis to Explicate Service Climate Themes," Journal of Applied Psychology, 1992, Vol.77, No.5, pp.705-16.

[26] Spreng, R.A. and A.K. Singh. "An Empirical Assessment of the SERVQUAL Scale and the Relationship between Service Quality and Satisfaction" unpublished paper, Michigan State University, 1993.

[27] Wemmerlov, U. "A Taxonomy for Service Processes and Its Implications for System Design”, International Journal of Service Industry Management, 1990, Vol. 1 No. 3, pp. 20-40.

[28] Zeithaml, Valarie A., Parasuraman, A., and Berry, L.L. Delivering Quality Service: Balancing Customer Perceptions and Expectations. New York: The Free Press, 1990. 